\title{
Comparative studies on the role of benzoic, t-cinnamic, and salicylic acids on growth, some biochemical aspects, and yield of three flax cultivars grown under sandy soil conditions
}

\author{
Mona G. Dawood ${ }^{1 *}$ (D, Mervat Sh. Sadak¹, Bakry A. Bakry² and Mohamed F. El Karamany ${ }^{2}$
}

\begin{abstract}
Background and objective: Phenolic compounds are low molecular compounds present in all tissues of higher plants and play an important role in plant development. A field experiment was carried out during two winter seasons 2014/2015 and 2015/2016 to compare the role of benzoic, t-cinnamic, or salicylic acids on some growth and biochemical parameters as well as the seed yield of three flax cultivars grown under sandy soil conditions.

Results: Results show the superiority of Blanka cultivar in some growth parameters, photosynthetic pigments, indole acetic acid (IAA), phenolic contents, seed yield, and some yield components. Application of different phenolic acids enhanced growth parameters, photosynthetic pigments, IAA, phenolic contents, seed yield, and yield components as well as oil and carbohydrate percentages in the yielded seeds.

Conclusion: Salicylic acid was the most efficient phenolic acids in increasing most of the studied growth and yield parameters via improving various studied biochemical parameters, where salicylic acid at $100 \mathrm{mg} / \mathrm{l}$ was the most effective treatment on the three tested cultivars.
\end{abstract}

Keywords: Flax, Benzoic acid, t-Cinnamic acid, Salicylic acid, Seed yield, Seed quality

\section{Introduction}

The flax (Linum usitatissimum L.) plant is one of the most important oilseed and fiber crops in the world. In Egypt, flax is grown as a dual purpose crop, i.e., fiber and seed oil (El Hariri et al. 2010). Flax seeds show a very high antioxidant activity, and the main antioxidant present in flax seed is ascorbic acid (Morris 2005). Flax seeds have a high content of oil that is characterized by the presence of essential fatty acids as omega 3, 6, and 9 groups of fatty acids for good health (Johnson et al. 2008). With huge increases in populations and a great loss of agricultural soils due to desertification and erosion problems, Egypt suffers from human oil shortage

\footnotetext{
* Correspondence: monagergis@yahoo.com

${ }^{1}$ Botany Department, Agricultural and Biological Division, National Research Centre, Giza P.O. 12622, Egypt

Full list of author information is available at the end of the article
}

problem. So, it is necessary to increase the productivity of oil seed plants as flax plant. Thus, reclaimed sandy soil has gained great attention. Reclaimed sandy soil is mostly exposed to different environmental stress conditions such as nutrient shortage, low availability of water, changes in temperature, and high irradiances. Thus, it is important to increase plant tolerance to such conditions through selecting tolerant genotypes and applying the optimum cultural practices and/or treating seeds before sowing or plants at different growth stages with some growth regulators or antioxidant compounds that play an important role for helping plants to overcome partially the unfavorable conditions and avoid their negative effects on crop yield quantity and quality. So flax production can be increased by two means, either by horizontal expansion (cultivation in newly reclaimed lands) 
Table 1 Mechanical, chemical, and nutritional analysis of the experimental soil

\begin{tabular}{|c|c|c|c|c|c|c|c|c|c|c|c|c|}
\hline \multirow{3}{*}{$\begin{array}{l}\text { Mechanical } \\
\text { analysis }\end{array}$} & \multicolumn{6}{|l|}{ Sand } & \multicolumn{2}{|c|}{ Silt 20-0 $\mu \%$} & \multicolumn{2}{|c|}{ Clay $<2 \mu \%$} & \multicolumn{2}{|c|}{ Soil texture } \\
\hline & \multicolumn{3}{|c|}{ Course $2000-200 \mu \%$} & \multicolumn{3}{|c|}{ Fine $200-20 \mu \%$} & & & & & & \\
\hline & \multicolumn{3}{|c|}{47.46} & \multicolumn{3}{|c|}{36.19} & \multicolumn{2}{|l|}{12.86} & \multicolumn{2}{|l|}{4.28} & \multicolumn{2}{|c|}{ Sandy } \\
\hline \multirow[t]{3}{*}{ Chemical analysis } & \multirow{2}{*}{$\begin{array}{l}\mathrm{pH} \\
1: 2.5\end{array}$} & \multirow{2}{*}{$\begin{array}{l}\mathrm{EC} \\
\mathrm{dSm} \mathrm{m}^{-1}\end{array}$} & \multirow{2}{*}{$\begin{array}{l}\mathrm{CaCO}_{3} \\
\%\end{array}$} & \multirow[t]{2}{*}{$\mathrm{OM} \%$} & \multicolumn{4}{|c|}{ Soluble cations (meq/l) } & \multicolumn{4}{|c|}{ Soluble anions (meq/l) } \\
\hline & & & & & $\mathrm{Na}^{+}$ & $\mathrm{K}^{+}$ & $\mathrm{Mg}^{+}$ & $\mathrm{Ca}^{++}$ & $\mathrm{CO}_{3}^{--}$ & $\mathrm{HCO}_{3}^{-}$ & $\mathrm{Cl}^{-}$ & $\mathrm{SO}_{4}^{-}$ \\
\hline & 8.25 & 0.11 & 0.9 & 0.9 & 0.7 & 0.02 & 0.1 & 0.3 & 0.0 & 0.2 & 0.8 & 0.12 \\
\hline \multirow[t]{4}{*}{ Nutritional analysis. } & \multicolumn{12}{|c|}{ Available nutrients } \\
\hline & \multicolumn{5}{|c|}{ Macro element (ppm) } & \multicolumn{5}{|c|}{ Micro element (ppm) } & & \\
\hline & \multicolumn{2}{|l|}{$N$} & $P$ & \multicolumn{2}{|l|}{ K } & Zn & \multicolumn{2}{|l|}{$\mathrm{Fe}$} & \multicolumn{2}{|l|}{$\mathrm{Mn}$} & \multicolumn{2}{|l|}{$\mathrm{Cu}$} \\
\hline & \multicolumn{2}{|l|}{12.9} & 3.6 & \multicolumn{2}{|l|}{52.9} & 0.12 & \multicolumn{2}{|l|}{1.98} & \multicolumn{2}{|l|}{0.46} & \multicolumn{2}{|l|}{0.06} \\
\hline
\end{tabular}

or by vertical expansion (using phenolic acids, amino acids, vitamins, antioxidant, or growth regulators).

Phenolic compounds are considered as secondary plant metabolites that are present in all tissues of higher plants, play an important role as a signal molecule in certain symbiotic relationships, and act as defense molecules against soil pests and pathogens (Makoi and Ndakidemi 2007). Furthermore, these biomolecules may contribute to soil and water conservation, weed management, and mineral element nutrition. Benzoic acid, t-cinnamic acid, and salicylic acid are phenolic acids; many investigators demonstrated the role of these phenolic acids in improving plant growth and productivity. They reported the synthesis of large amounts of phenylpropanoid acids, mainly hydroxylcinnamic acids and hydroxyl-benzoic acid (Dixon 2001). In addition, benzoic acid and t-cinnamic acid is a key intermediate in shikimate and phenylpropanoid pathways. Shikimic acid is a precursor of many alkaloids, aromatic amino acids, and indole derivatives. Benzoic acid is a biosynthetic precursor of salicylic acid and has been tested in different crops (Raskin 1992). Benzoic acid is known to provide abiotic stress tolerance (Senaratna et al., 2003). Tcinnamic acid is used as a component of plant-derived flavorings (Hoskins 1984). It belongs to the class of plant growth regulator namely auxin, that regulate cell growth and differentiation (Thimann 1969). Also, t-cinnamic acid

Table 2 Effect of cultivars on growth parameters of flax plants grown under sandy soil conditions (data are means of two seasons)

\begin{tabular}{|c|c|c|c|c|}
\hline \multirow[t]{2}{*}{ Parameters } & \multicolumn{3}{|c|}{ Cultivars } & \multirow{2}{*}{$\begin{array}{l}\text { LSD } \\
\text { at } \\
0.05\end{array}$} \\
\hline & Blanka & Line-4 & Giza-8 & \\
\hline Shoot length (cm) & 61.87 & 52.33 & 63.44 & 2.35 \\
\hline No. of basal branches/plant & 2.70 & 2.94 & 1.57 & 0.18 \\
\hline Shoot fresh wt/plant (g) & 9.88 & 5.48 & 7.69 & 1.33 \\
\hline Shoot dry wt/plant (g) & 1.01 & 0.6 & 0.86 & 0.21 \\
\hline Root length (cm) & 11.83 & 12.45 & 13.00 & 0.41 \\
\hline Root fresh wt/plant (g) & 1.25 & 0.73 & 1.09 & 0.12 \\
\hline Root dry wt/plant (g) & 0.24 & 0.12 & 0.31 & 0.10 \\
\hline
\end{tabular}

is present in a variety of secondary metabolites of phenylpropanoid biosynthetic origin (Epifano et al. 2007). Salicylic acid (2-hydroxybenzoic acid) is an important signal molecule involved in the improving of plant tolerance against abiotic and biotic stresses and plays a crucial role for the regulation of physiological and biochemical processes (Saruhan and Kadioglu, 2012). Salicylic acid is considered a hormone-like endogenous regulator that affects a range of diverse processes in plants, including seed germination, ion uptake and transport, membrane permeability, and photosynthesis (Simaei et al. 2011). Effects of salicylic acid on plants depend on its concentration, its duration of treatment, its plant species, the age of the plant, and the plant organ used for pretreatment (Shi et al. 2009). Additionally, salicylic acid is beneficial to the utilization of carbon source, thus leading to significant increase in the content of polysaccharides (Wang et al. 2010). Recently, salicylic acid has been studied as a signal molecule mediating local and systemic defense responses against different abiotic stresses (Sadak 2016).

Therefore, this study was undertaken to study the physiological role of benzoic, $t$-cinnamic, and salicylic acids on some growth parameters, yield quantity, and quality of flax plant grown under sandy soil conditions.

\section{Materials and methods}

Two field experiments were carried out at Researches and Production Station of National Research Centre, Al Nubaria district El-Behira Governorate, Egypt, during two successive winter seasons 2014/2015 and 2015/2016. Soil of the experimental site was sandy soil. Mechanical, chemical, and nutritional analysis of the experimental soil is reported in Table 1 according to Chapman and Pratt (1978).

The experimental design was a split-split plot design with three replicates, where the flax cultivars (Blanka, Line-4, and Giza-8) were in the main plots, while, phenolic acids (benzoic, t-cinnamic, or salicylic acids) occupied the sub plots and the concentrations $(0,50,75$, and $100 \mathrm{mg} / \mathrm{l})$ were allocated at random in sub-subplots. Flax seed cultivars were sown on 17 November in both 
Table 3 Effect of cultivars on photosynthetic pigments, IAA, and phenolic contents of flax plants grown under sandy soil conditions (data are means of two successive seasons)

\begin{tabular}{lllllll}
\hline Cultivars & Chlorophyll a (mg/g FW) & Chlorophyll b (mg/g FW) & $\begin{array}{l}\text { Carotenoids } \\
(\mathrm{mg} / \mathrm{g} \mathrm{FW})\end{array}$ & $\begin{array}{l}\text { Total pigments } \\
(\mathrm{mg} / \mathrm{g} \mathrm{FW})\end{array}$ & $\begin{array}{l}\text { IAA } \\
(\mu \mathrm{gg} / \mathrm{g} \mathrm{FW})\end{array}$ & Phenolic content (mg/100 $\mathrm{FW})$ \\
\hline Blanka & 1.665 & 0.614 & 0.533 & 2.812 & 47.37 & 100.43 \\
Line-4 & 1.494 & 0.567 & 0.485 & 2.546 & 32.43 & 68.74 \\
Giza-8 & 1.366 & 0.563 & 0.416 & 2.345 & 47.01 & 100.03 \\
LSD 0.05 & 0.135 & 0.023 & 0.041 & 0.120 & 0.67 & 1.42 \\
\hline
\end{tabular}

seasons in rows $3.5 \mathrm{~m}$ long and the distance between rows was $20 \mathrm{~cm}$ apart, plot area was $10.5 \mathrm{~m}^{2}(3.0 \mathrm{~m}$ in width and $3.5 \mathrm{~m}$ in length). The seeding rate was 2000 seeds $/ \mathrm{m}^{2}$. Pre-sowing, $150(\mathrm{~kg} / \mathrm{fed}$.) of calcium superphosphate $\left(15.5 \% \mathrm{P}_{2} \mathrm{O}_{5}\right)$ was added. Nitrogen was applied after emergence in the form of ammonium nitrate $33.5 \%$ at rate of $75 \mathrm{~kg} / \mathrm{fed}$ in five equal doses. Potassium sulfate $\left(48 \% \mathrm{~K}_{2} \mathrm{O}\right)$ was added at two equal doses of 50 $\mathrm{kg} /$ fed. Irrigation was carried out using the new sprinkler irrigation system where water was added every 5 days. Foliar application of different treatments of benzoic, $\mathrm{t}$ cinnamic, and salicylic acid at $0,50,75$, and $100 \mathrm{mg} / \mathrm{l}$ were applied twice after 30 and 45 days from sowing. Plant samples were taken after 60 days from sowing for measurements of growth parameters and some biochemical parameters. Growth parameters in terms of shoot length $(\mathrm{cm})$, number of basal branches/plant, shoot fresh and dry weight $(\mathrm{g})$, root length $(\mathrm{cm})$, and root fresh and dry weight (g). Plant samples were dried in an electric oven with drift fan at $70^{\circ} \mathrm{C}$ for $48 \mathrm{~h}$ till constant dry weight. At harvest, flax plants were pulled when signs of full maturity appeared and then left on the ground to suitable complete drying. Capsules were removed carefully. Plant height, technical stem length, fruiting zone length, number of fruiting branches/plant, number of capsules/ plant, seed yield/plant, and biological yield/plant were recorded on random samples of ten guarded plants in each plot. Also, seed yield/fed, straw yield/fed, seed oil\% and oil yield/fed, and carbohydrates\% were studied.

\section{Biochemical analysis}

Photosynthetic pigment contents (chlorophyll a and b and carotenoids) in fresh leaves were estimated using the method of Lichtenthaler and Buschmann (2001).
Indole acetic acid content was extracted and analyzed by the method of Larsen et al. (1962). Total phenolic content was determined as described by Danil and George (1972). Determination of total carbohydrates of seeds was carried out according to Herbert et al. (1971). The oil of flax seeds was extracted according to Kates and Eberhardt (1957).

\section{Statistical analysis}

The analysis of variance for a split-split plot design was carried out for each studied character in each season. The combined analysis for data from the two seasons was carried out for all aforementioned parameters according to (Snedecor and Cochran, 1980) as the results of two seasons followed a similar trend. Means were compared by L.S.D. test at 0.05 probability level.

\section{Results}

Effect of cultivar differences on growth parameters, biochemical constituents, yield, and yield components of flax

Different growth parameters (shoot and root length $(\mathrm{cm})$, number of basal branches/plant, fresh and dry weight of shoot and root (g)/plant as presented in Table 2) showed significant differences between means of flax cultivars under study. Blanka cultivar significantly surpassed Line-4 and Giza-8 in shoot fresh and dry weight as well as root fresh weight. Line-4 cultivar surpassed the other two flax cultivars in number of basal branches/plant. Moreover, Giza-8 cultivar surpassed the two other cultivars on shoot length, root length, and root dry weight/plant.

Results presented in Table 3 demonstrate the effect of cultivars on photosynthetic pigments (chlorophyll a,

Table 4 Effect of cultivars on seed yield, its components, and oil and carbohydrate percentages of flax plants grown under sandy soil conditions (data are means of two successive seasons)

\begin{tabular}{|c|c|c|c|c|c|c|c|c|c|c|c|c|c|}
\hline Cultivars & $\begin{array}{l}\text { Plant } \\
\text { height } \\
(\mathrm{cm})\end{array}$ & $\begin{array}{l}\text { Fruiting } \\
\text { zone length } \\
(\mathrm{cm})\end{array}$ & $\begin{array}{l}\text { Technical } \\
\text { length }(\mathrm{cm})\end{array}$ & $\begin{array}{l}\text { Biol. } \\
\text { yield/ } \\
\text { plant } \\
\text { (g) }\end{array}$ & $\begin{array}{l}\text { No. of } \\
\text { fruiting } \\
\text { branches/ } \\
\text { plant }\end{array}$ & $\begin{array}{l}\text { No. of } \\
\text { capsules/ } \\
\text { plant }\end{array}$ & $\begin{array}{l}\text { Seed yield/ } \\
\text { plant (g) }\end{array}$ & $\begin{array}{l}1000 \\
\text { Seeds wt. } \\
\text { (g) }\end{array}$ & $\begin{array}{l}\text { Biol. } \\
\text { yield } \\
\text { (ton/ } \\
\text { fed) }\end{array}$ & $\begin{array}{l}\text { Seed yield } \\
\text { (kg/fed) }\end{array}$ & $\begin{array}{l}\text { Oil yield } \\
\text { (kg/fed) }\end{array}$ & Oil\% & Carbohydrate\% \\
\hline Blanka & 76.03 & 26.77 & 49.26 & 18.55 & 21.53 & 103.23 & 5.38 & 7.67 & 3.033 & 528.52 & 130.33 & 24.66 & 27.76 \\
\hline Line-4 & 75.02 & 26.36 & 48.66 & 10.39 & 14.19 & 61.71 & 3.07 & 7.73 & 3.424 & 620.56 & 148.69 & 23.96 & 29.88 \\
\hline Giza-8 & 82.57 & 28.24 & 54.33 & 8.92 & 10.70 & 49.40 & 3.19 & 9.31 & 3.190 & 592.58 & 130.66 & 22.05 & 32.06 \\
\hline $\begin{array}{l}\text { LSD } \\
0.05\end{array}$ & 2.55 & 1.33 & 1.50 & 2.19 & 2.13 & 5.66 & 0.25 & 0.11 & 0.18 & 27.58 & 0.0524 & 0.19 & 0.21 \\
\hline
\end{tabular}


Table 5 Effect of phenolic acid treatments on growth parameters of flax plants grown under sandy soil conditions (data are means of two seasons)

\begin{tabular}{llllllll}
\hline Treatments & $\begin{array}{l}\text { Shoot length } \\
(\mathrm{cm})\end{array}$ & $\begin{array}{l}\text { No. of basal } \\
\text { branches }\end{array}$ & $\begin{array}{l}\text { Shoot fresh wt./ } \\
\text { plant }(\mathrm{g})\end{array}$ & $\begin{array}{l}\text { Shoot dry wt./ } \\
\text { plant }(\mathrm{g})\end{array}$ & $\begin{array}{l}\text { Root length } \\
(\mathrm{cm})\end{array}$ & $\begin{array}{l}\text { Root fresh wt./ } \\
\text { plant }(\mathrm{g})\end{array}$ & $\begin{array}{l}\text { Root dry wt./ } \\
\text { plant }(\mathrm{g})\end{array}$ \\
\hline Benzoic acid & 57.09 & 2.06 & 7.31 & 0.82 & 11.37 & 1.10 & 0.29 \\
$\begin{array}{l}\text { T-cinnamic } \\
\text { acid }\end{array}$ & 56.89 & 2.25 & 7.53 & 0.76 & 11.99 & 0.93 & 0.15 \\
Salicylic acid & 56.42 & 2.06 & 7.12 & 0.77 & 11.93 & 0.92 & 0.17 \\
LSD 0.05 & 0.32 & 0.05 & 0.12 & 0.03 & 0.05 & 0.02 & 0.01 \\
\hline
\end{tabular}

chlorophyll b, carotenoids, and total photosynthetic pigments). Results clearly show significant differences in photosynthetic pigments between cultivars (Blanka, Line-4, and Giza-8). Blanka cultivar surpassed Line-4 and Giza- 8 cultivars as it gives the highest content of photosynthetic pigment constituents.

The results reported in Table 3 show that there are significant differences between cultivars on IAA and phenolic contents of flax plants grown under sandy soil conditions. IAA of Blanka and Giza-8 cultivars surpassed the Line-4 cultivar (47.37 and $47.01 \mu \mathrm{g} / \mathrm{g}$ FW) and phenolic contents of Blanka and Giza-8 cultivars surpassed Line-4 cultivar (100.43 and $100.03 \mathrm{mg} / \mathrm{g}$ FW) respectively.

Table 4 shows the effect of cultivars on seed yield, its components, oil\%, and carbohydrate\% of the three tested cultivars; results clearly show the presence of marked differences between cultivars in seed yield and its components. Blanka cultivar surpassed the two other cultivars in biological yield (18.55/plant g), number of branches (21.53), and capsules/plant (103.23), seed yield/plant (5.38), and oil\% (24.66). Meanwhile, Line-4 gave the highest biological yield (3.42 ton/fed) and seed yield $(620.56 \mathrm{~kg} / \mathrm{fed})$. Whereas, Giza-8 cultivar was surpassed over the other two cultivars in plant height $(82.57 \mathrm{~cm})$, fruiting zone length $(28.24 \mathrm{~cm})$, technical length $(54.33 \mathrm{~cm}), 1000$ seeds weight $(9.31 \mathrm{~g})$, and carbohydrate\% (32.06\%) of the yielded seeds.

\section{Effect of benzoic, t-cinnamic, and salicylic acids on growth parameters, biochemical constituents, seed yield, and its components}

Different phenolic acid treatment (benzoic acid, tcinnamic acid, and salicylic acid) effects on growth parameters of flax plant are presented in Table 5. The results show marked differences between different treatments on growth parameters of flax plant.

Different phenolic acid treatments showed marked differences in photosynthetic pigments, IAA, and phenolic contents between treatments as presented in Table 6 .

The results presented in Table 7 show that there were marked differences among all treatments of benzoic, $t$ cinnamic acid, and salicylic acids on all studied parameters (seed yield, yield components, oil\%, and carbohydrate\%) of flax cultivars grown under sandy soil. Salicylic acid gives the highest increases in plant height, fruiting zone length, biological yield/plant, number of capsules/ plant, seed yield/plant, biological yield/fed, seed yield/ fed, oil yield/fed, oil\%, and carbohydrate\%. While benzoic acid gave the highest technical shoot length, number of branches/plant, and 1000 seeds weight.

\section{Effect of phenolic acid concentrations on growth parameters, biochemical constituents, seed yield, and its components}

Effects of phenolic acid concentrations on growth parameters of flax plant are presented in Table 8. Data show that different concentrations $(50,75$, and $100 \mathrm{mg} / \mathrm{l})$ caused significant increases in different growth criteria of flax plant as compared with untreated control plant. The most effective concentration was $75 \mathrm{mg} / \mathrm{l}$ in most studied parameters.

The effect of different phenolic acid concentration (50, 75 , and $100 \mathrm{mg} / \mathrm{l}$ ) on photosynthetic pigments, indole acetic acid (IAA), and phenolic contents of flax plant are presented in Table 9. Treatment of flax plant with

Table 6 Effect of phenolic acid treatments on photosynthetic pigments, IAA and phenolic contents of flax plants grown under sandy soil conditions (Data are means of two successive seasons)

\begin{tabular}{lllllll}
\hline Treatments & $\begin{array}{l}\text { Chlorophyll a (mg/g } \\
\text { FW) }\end{array}$ & $\begin{array}{l}\text { Chlorophyll b (mg/g } \\
\text { FW) }\end{array}$ & $\begin{array}{l}\text { Carotenoids } \\
(\mathrm{mg} / \mathrm{g} \text { FW) }\end{array}$ & $\begin{array}{l}\text { Total } \\
\text { pigments } \\
(\mathrm{mg} / \mathrm{g} \mathrm{FW})\end{array}$ & $\begin{array}{l}\text { IAA }(\mu \mathrm{g} / \mathrm{g} \\
\text { FW })\end{array}$ & $\begin{array}{l}\text { Phenolic content (mg/100 g } \\
\text { FW) }\end{array}$ \\
\hline Benzoic acid & 1.513 & 0.547 & 0.465 & 2.524 & 36.43 & 77.23 \\
$\begin{array}{l}\text { T-cinnamic } \\
\text { acid }\end{array}$ & 1.435 & 0.532 & 0.470 & 2.436 & 39.22 & 83.16 \\
Salicylic acid & 1.444 & 0.606 & 0.464 & 2.514 & 42.01 & 89.06 \\
LSD 0.05 & 0.011 & 0.037 & 0.033 & 0.010 & 1.020 & 2.15 \\
\hline
\end{tabular}


Table 7 Effect phenolic acid treatments on seed yield, its components, and oil and carbohydrate percentages of flax plants grown under sandy soil conditions (data are means of two successive seasons)

\begin{tabular}{|c|c|c|c|c|c|c|c|c|c|c|c|c|c|}
\hline Treatments & $\begin{array}{l}\text { Plant } \\
\text { height } \\
(\mathrm{cm})\end{array}$ & $\begin{array}{l}\text { Fruiting } \\
\text { zone } \\
\text { length } \\
(\mathrm{cm})\end{array}$ & $\begin{array}{l}\text { Technical } \\
\text { length } \\
(\mathrm{cm})\end{array}$ & $\begin{array}{l}\text { Biol. } \\
\text { yield/ } \\
\text { plant } \\
\text { (g) }\end{array}$ & $\begin{array}{l}\text { No. of } \\
\text { branches/ } \\
\text { plant }\end{array}$ & $\begin{array}{l}\text { No. of } \\
\text { capsules/ } \\
\text { plant }\end{array}$ & $\begin{array}{l}\text { Seed } \\
\text { yield/ } \\
\text { plant (g) }\end{array}$ & $\begin{array}{l}1000 \\
\text { Seeds } \\
\text { wt. (g) }\end{array}$ & $\begin{array}{l}\text { Biol. yield } \\
\text { (ton/fed) }\end{array}$ & $\begin{array}{l}\text { Seed } \\
\text { yield (kg/ } \\
\text { fed) }\end{array}$ & $\begin{array}{l}\text { Oil } \\
\text { yield } \\
\mathrm{Kg} / \\
\text { fed }\end{array}$ & Oil\% & Carbo\% \\
\hline $\begin{array}{l}\text { Benzoic } \\
\text { acid }\end{array}$ & 79.36 & 27.89 & 51.47 & 11.82 & 15.09 & 69.67 & 3.58 & 8.14 & 2.968 & 509.57 & 118.48 & 23.25 & 29.68 \\
\hline $\begin{array}{l}\text { T-cinnamic } \\
\text { acid }\end{array}$ & 76.94 & 29.03 & 47.92 & 10.35 & 14.16 & 60.08 & 3.21 & 7.94 & 3.036 & 554.33 & 112.14 & 20.23 & 29.07 \\
\hline $\begin{array}{l}\text { Salicylic } \\
\text { acid }\end{array}$ & 79.94 & 30.64 & 49.31 & 12.23 & 14.89 & 65.69 & 3.84 & 7.92 & 3.107 & 583.08 & 118.07 & 20.25 & 29.67 \\
\hline $\mathrm{LSD}_{0.05}$ & 2.05 & 1.13 & 1.33 & 0.28 & 0.33 & 3.15 & 0.21 & 0.02 & 0.071 & 15.33 & 12.65 & 0.01 & 0.01 \\
\hline
\end{tabular}

different phenolic acid concentrations caused significant increases in photosynthetic pigments, IAA, and phenolic contents as compared with untreated control plant.

The results presented in Table 10 show that different phenolic acid concentrations increased significantly seed yield and its components of flax cultivars grown under sandy soil conditions as compared with control plants. The most effective concentration was $75 \mathrm{mg} / \mathrm{l}$.

\section{Effect of cultivars and benzoic acid, t-cinnamic acid and salicylic acid on growth parameters, biochemical constituents, seed yield, and its components}

Data presented in Table 11 show the effect of cultivars (Blanka, Line-4 and Giza-8) and the used phenolic acids (Benzoic, t-cinnamic and salicylic acids) on growth parameters. Data clearly show that Blanka cultivar shows the superiority of salicylic acid treatment on shoot length and dry weight, root length and fresh weight; meanwhile, t-cinnamic acid was superior in increasing shoot fresh weight and root dry weight. Moreover, Line4 shows the superiority of $t$-cinnamic acid on shoot length, number of basal branches and shoot fresh weight and root dry weight, while benzoic acid was superior in root length and fresh weight. Finally, Giza-8 cultivar shows the superiority of benzoic acid in number of basal branches, shoot and root fresh and dry weight.

The effect of cultivars and different phenolic acids used (benzoic, t-cinnamic, and salicylic acids) on photosynthetic pigments, indole acetic acid (IAA), and phenolic contents of flax plant are presented in Table 12. Blanka cultivar shows the superiority of salicylic acid treatment on photosynthetic pigments, IAA, and phenolic over the two used treatments ( $\mathrm{t}$-cinnamic and salicylic acid). Meanwhile, the used treatments (benzoic, tcinnamic, and salicylic acid) caused various changes in the other two cultivars (Line-4 and Giza-8) in different studied parameters.

The changes in seed yield and its components of the three cultivars of flax plant and foliar treatments with benzoic acid, t-cinnamic acid, and salicylic acid are presented in Table 13. Cultivars and different phenolic acid treatments show marked changes in seed yield and its components; Blanka and Line- 4 cultivars show the highest increases in biological yield (ton/fed), seed yield, and oil yield $(\mathrm{kg} / \mathrm{fed})$ by salicylic acid treatment. Meanwhile, Giza-8 cultivar shows the highest increase with tcinnamic treatment.

Effect of cultivars and phenolic acid concentrations on growth parameters, biochemical constituents, seed yield, and its components

The effect of three cultivars and different phenolic acid concentrations on growth parameters of flax plant are presented in Table 14. Data show marked and significant increases of different growth parameters of the tested flax cultivars as compared with untreated control plants. Seventy-five milligrams per liter concentration was the most effective concentration in general in increasing

Table 8 Effect of concentrations on growth criteria of flax plants grown under sandy soil conditions (data are means of two seasons)

\begin{tabular}{llllllll}
\hline $\begin{array}{l}\text { Concentrations } \\
(\mathrm{mg} / \mathrm{l})\end{array}$ & $\begin{array}{l}\text { Shoot length } \\
(\mathrm{cm})\end{array}$ & $\begin{array}{l}\text { No. of basal } \\
\text { branches }\end{array}$ & $\begin{array}{l}\text { Shoot fresh wt/ } \\
\text { plant }(\mathrm{g})\end{array}$ & $\begin{array}{l}\text { Shoot dry wt/ } \\
\text { plant }(\mathrm{g})\end{array}$ & $\begin{array}{l}\text { Root length } \\
(\mathrm{cm})\end{array}$ & $\begin{array}{l}\text { Root fresh wt/ } \\
\text { plant (g) }\end{array}$ & $\begin{array}{l}\text { Root dry wt/ } \\
\text { plant (g) }\end{array}$ \\
\hline Control & 44.11 & 1.56 & 4.93 & 0.57 & 8.11 & 0.67 & 0.09 \\
50 & 56.93 & 2.22 & 7.11 & 0.77 & 12.44 & 0.91 & 0.21 \\
75 & 63.70 & 2.41 & 8.62 & 0.92 & 13.52 & 1.17 & 0.25 \\
100 & 62.45 & 2.29 & 8.63 & 0.87 & 12.98 & 1.17 & 0.26 \\
$\mathrm{LSD}_{0.05}$ & 1.03 & 0.11 & 0.21 & 0.05 & 0.13 & 0.03 & 0.01 \\
\hline
\end{tabular}


Table 9 Effect of phenolic acid concentrations on photosynthetic pigments, IAA, and phenolic contents of flax plants grown under sandy soil conditions (data are means of two successive seasons)

\begin{tabular}{lllllll}
\hline Concentrations (mg/L) & Chlorophyll a (mg/g FW) & Chlorophyll b (mg/g FW) & $\begin{array}{l}\text { Carotenoids } \\
(\mathrm{mg} / \mathrm{g} \mathrm{FW})\end{array}$ & $\begin{array}{l}\text { Total pigments } \\
(\mathrm{mg} / \mathrm{g} \mathrm{FW})\end{array}$ & $\begin{array}{l}\text { IAA } \\
(\mu \mathrm{g} / \mathrm{g} \text { FW })\end{array}$ & Phenolic content (mg/100 g FW) \\
\hline Control & 1.192 & 0.445 & 0.391 & 2.028 & 23.47 & 49.76 \\
50 & 1.506 & 0.559 & 0.453 & 2.518 & 35.74 & 75.76 \\
75 & 1.561 & 0.602 & 0.503 & 2.666 & 49.49 & 104.60 \\
100 & 1.596 & 0.639 & 0.519 & 2.754 & 48.18 & 102.47 \\
LSD 0.05 & 0.022 & 0.031 & 0.015 & 0.11 & 1.150 & 1.060 \\
\hline
\end{tabular}

different growth parameters of Blanka cultivar. On the other hand, $100 \mathrm{mg} / \mathrm{l}$ was the most effective concentration in Line-4 and Giza-8 cultivars in most studied growth parameters.

The effect of cultivars and different phenolic acid concentrations used $(0.0,50,75$, and $100 \mathrm{mg} / \mathrm{l})$ on photosynthetic pigments, indole acetic acid (IAA), and phenolic contents of flax plant are presented in Table 15. Blanka and Line-4 cultivars show that $100 \mathrm{mg} / \mathrm{l}$ was the most effective concentration on increasing different photosynthetic pigment constituents, IAA, and phenolic contents compared with the other used treatments. Meanwhile, $75 \mathrm{mg} / \mathrm{l}$ was the most effective concentration on Giza-8 photosynthetic pigments, while $100 \mathrm{mg} / \mathrm{l}$ was most effective on increasing IAA and phenolic contents over the two other concentrations.

The results reported in Table 16 show that there were significant increases of different studied characters (seed yield, yield components, oil\%, and carbohydrate\%) of three flax cultivars with 50,75 , and $100 \mathrm{mg} / \mathrm{l}$ treatments compared with those untreated plants. Seventy-five milligrams per liter was the most effective concentration in increasing most of the studied yield parameters of Blanka and Line-4 cultivars; meanwhile, the highest increases of Giza-8 cultivar was obtained in some parameter by $75 \mathrm{mg} / \mathrm{l}$ and others by $100 \mathrm{mg} / \mathrm{l}$ compared with control plants.

\section{Effect of benzoic acid, t-cinnamic acid and salicylic acid levels on growth parameters, biochemical constituents, seed yield, and its components}

The effect of foliar treatment with benzoic acid, tcinnamic acid, and salicylic acid on growth parameters (shoot and root length, number of basal branches/plant, fresh and dry weight of shoot and root) of flax plant are presented in Table 17. The results show that different treatments significantly increased growth parameters of flax plant. Seventy-five milligrams per liter of benzoic and $\mathrm{t}$-cinnamic acids were more effective than 50 and $100 \mathrm{mg} / \mathrm{l}$ of both acids; meanwhile, $100 \mathrm{mg} / \mathrm{l}$ of salicylic acid was more effective than 50 and $75 \mathrm{mg} / \mathrm{l}$. Benzoic acid treatment at $75 \mathrm{mg} / \mathrm{l}$ was the most effective treatment on shoot length and fresh and dry weight of shoot. Meanwhile, $100 \mathrm{mg} / \mathrm{l}$ salicylic was the most effective treatment on root length and fresh and dry weight of root.

Regarding photosynthetic pigments, indole acetic acid (IAA), and phenolic contents, different treatments caused significant increases in photosynthetic pigments, IAA, and phenolic contents (Table 18). Seventy-five milligrams per liter benzoic acid and t-cinnamic acid was more effective than 50 and $100 \mathrm{mg} / \mathrm{l}$, while $100 \mathrm{mg} / \mathrm{l} \mathrm{sali-}$ cylic acid was the most effective concentration. In addition, salicylic acid at $100 \mathrm{mg} / \mathrm{l}$ was the most effective treatment on chlorophyll $\mathrm{b}$, carotenoids, total pigments, IAA, and phenolic contents; Meanwhile, benzoic acid at $75 \mathrm{mg} / \mathrm{l}$ concentration was the most effective concentration on chlorophyll a.

The results presented in Table 19 show that there were significant differences among all treatments of all studied characters (seed yield, yield components, oil\%, and carbohydrate\%) of flax cultivars grown under sandy soil. Both benzoic acid and t-cinnamic acid at $75 \mathrm{mg} / \mathrm{l}$ were more effective than 50 and $100 \mathrm{mg} / \mathrm{l}$ of both benzoic and $\mathrm{t}$-cinnamic acid, meanwhile, $100 \mathrm{mg} / \mathrm{l}$ was the most effective treatment of salicylic acid. Data indicated that the

Table 10 Effect phenolic acid concentrations on seed yield, its components, and oil and carbohydrate percentages of flax plants grown under sandy soil conditions (data are means of two successive seasons)

\begin{tabular}{|c|c|c|c|c|c|c|c|c|c|c|c|c|c|}
\hline $\begin{array}{l}\text { Conc } \\
(\mathrm{mg} / \mathrm{L})\end{array}$ & $\begin{array}{l}\text { Plant } \\
\text { height } \\
(\mathrm{cm})\end{array}$ & $\begin{array}{l}\text { Fruiting } \\
\text { zone length } \\
(\mathrm{cm})\end{array}$ & $\begin{array}{l}\text { Technical } \\
\text { length }(\mathrm{cm})\end{array}$ & $\begin{array}{l}\text { Biol. } \\
\text { yield/ } \\
\text { plant } \\
\text { (g) }\end{array}$ & $\begin{array}{l}\text { No. of } \\
\text { branches/ } \\
\text { plant }\end{array}$ & $\begin{array}{l}\text { No. of } \\
\text { capsules/ } \\
\text { plant }\end{array}$ & $\begin{array}{l}\text { Seed yield/ } \\
\text { plant (g) }\end{array}$ & $\begin{array}{l}1000 \\
\text { Seeds wt. } \\
\text { (g) }\end{array}$ & $\begin{array}{l}\text { Biol. yield } \\
\text { (ton/fed) }\end{array}$ & $\begin{array}{l}\text { Seed yield } \\
\text { (kg/fed) }\end{array}$ & $\begin{array}{l}\text { Oil yield } \\
\text { (kg/fed) }\end{array}$ & Oil\% & Carbo\% \\
\hline Control & 68.11 & 22.78 & 45.33 & 5.73 & 10.89 & 33.66 & 1.85 & 6.78 & 2.143 & 391.20 & 82.90 & 21.19 & 27.32 \\
\hline 50 & 78.22 & 27.37 & 50.85 & 10.33 & 11.62 & 49.15 & 2.70 & 7.77 & 2.790 & 523.89 & 119.87 & 22.88 & 29.65 \\
\hline 75 & 85.55 & 34.15 & 51.41 & 16.27 & 19.85 & 94.90 & 4.95 & 8.88 & 3.676 & 648.97 & 134.08 & 20.66 & 30.70 \\
\hline 100 & 83.11 & 32.45 & 50.66 & 13.55 & 16.48 & 82.89 & 4.67 & 8.55 & 3.538 & 631.92 & 127.90 & 20.24 & 30.21 \\
\hline $\begin{array}{l}\text { LSD } \\
0.05\end{array}$ & 2.05 & 1.20 & 0.27 & 1.12 & 1.03 & 5.02 & 0.23 & 0.18 & 0.123 & 13.75 & 8.26 & 0.31 & 0.35 \\
\hline
\end{tabular}


Table 11 Effect of cultivars and benzoic, t-cinnamic, and salicylic acids on growth parameters of flax plants grown under sandy soil conditions (data are means of two successive seasons)

\begin{tabular}{|c|c|c|c|c|c|c|c|c|}
\hline Cultivars & Materials & $\begin{array}{l}\text { Shoot length } \\
(\mathrm{cm})\end{array}$ & $\begin{array}{l}\text { No. of basal } \\
\text { branches }\end{array}$ & $\begin{array}{l}\text { Shoot fresh wt/ } \\
\text { plant (g) }\end{array}$ & $\begin{array}{l}\text { Shoot dry wt/ } \\
\text { plant (g) }\end{array}$ & $\begin{array}{l}\text { Root length } \\
(\mathrm{cm})\end{array}$ & $\begin{array}{l}\text { Root fresh wt/ } \\
\text { plant (g) }\end{array}$ & $\begin{array}{l}\text { Root dry wt/ } \\
\text { plant (g) }\end{array}$ \\
\hline \multirow[t]{3}{*}{ Blanka } & Benzoic & 59.92 & 3.00 & 9.26 & 1.00 & 9.08 & 1.25 & 0.23 \\
\hline & $\begin{array}{l}\text { T- } \\
\text { cinnamic }\end{array}$ & 62.11 & 2.89 & 10.33 & 0.90 & 13.28 & 1.17 & 0.27 \\
\hline & Salicylic & 64.22 & 2.11 & 10.27 & 1.13 & 14.05 & 1.33 & 0.23 \\
\hline \multirow[t]{3}{*}{ Line-4 } & Benzoic & 49.17 & 2.50 & 4.55 & 0.52 & 13.13 & 0.80 & 0.12 \\
\hline & $\begin{array}{l}\text { T- } \\
\text { cinnamic }\end{array}$ & 56.22 & 3.56 & 6.47 & 0.65 & 10.89 & 0.70 & 0.13 \\
\hline & Salicylic & 52.67 & 2.89 & 5.72 & 0.66 & 13.11 & 0.66 & 0.12 \\
\hline \multirow[t]{3}{*}{ Giza-8 } & Benzoic & 61.42 & 1.94 & 8.12 & 0.90 & 11.92 & 1.18 & 0.53 \\
\hline & $\begin{array}{l}\text { t- } \\
\text { Cinnamic }\end{array}$ & 63.11 & 1.78 & 6.82 & 0.78 & 14.67 & 0.97 & 0.45 \\
\hline & Salicylic & 66.45 & 1.67 & 7.97 & 0.87 & 12.78 & 1.09 & 0.51 \\
\hline LSD 0.05 & & 1.22 & 0.33 & 0.51 & 0.23 & 0.55 & 0.08 & 0.05 \\
\hline
\end{tabular}

highest seed yield $(723.73 \mathrm{~kg} / \mathrm{fed})$, biological yield $(3.880$ ton/fed), seed yield/plant $(6.09 \mathrm{~g})$, and plant height $(88.66 \mathrm{~cm})$ were obtained at $100 \mathrm{mg} / \mathrm{l}$ salicylic acid. Meanwhile, foliar treatment with benzoic acid at $75 \mathrm{mg} / \mathrm{l}$ was the most effective treatment in fruiting zone length $(33.67 \mathrm{~cm})$, technical length $(53.44 \mathrm{~cm})$, biological yield/ plant (17.01 g), number of capsules/plant (101.70), and 1000 seeds weight $(9.45 \mathrm{~g})$ in addition to oil\% $(25.09 \%)$ and carbohydrate\% (30.95\%). While $75 \mathrm{mg} / \mathrm{l} \mathrm{t}$-cinnamic acid shows the highest number of branches/plant (21).

Effect of interaction between flax cultivars and benzoic, $t$ cinnamic or salicylic acids on growth parameters, biochemical constituents, seed yield, and its components The data presented in Tables 20, 21 and 22 show the interaction effects between cultivars and different treatments at different concentrations (benzoic, t-cinnamic, and salicylic acids) on different growth parameters, some biochemical constituents, and seed yield. Different treatment increased significantly all the studied growth parameters as compared with their corresponding controls of the three flax cultivars Blanka, Line-4, and Giza-8. Data presented in Tables 20, 21 and 22 show the promotive effects of different concentrations of the tested phenolic acids on the three flax cultivars.

Data presented in Table 21 reveal the significant increases in response to the interaction between flax cultivars and foliar treatments at different concentrations of benzoic, t-cinnamic, and salicylic acids. Blanka cultivar treated with $100 \mathrm{mg} / \mathrm{l}$ salicylic acid was the most effective treatment on chlorophyll $\mathrm{b}$ and total pigments, while foliar treatment at $75 \mathrm{mg} / \mathrm{l}$ gave the highest increases in chlorophyll a and carotenoid content as compared with untreated control plant. Meanwhile, in Line-4, salicylic

Table 12 Effect of cultivars and benzoic, t-cinnamic, and salicylic acids on photosynthetic pigments, IAA, and phenolic contents of flax plants grown under sandy soil conditions (data are means of two successive seasons)

\begin{tabular}{|c|c|c|c|c|c|c|c|}
\hline Cultivars & Materials & $\begin{array}{l}\text { Chlorophyll a } \\
\text { (mg/g FW) }\end{array}$ & Chlorophyll b & Carotenoids & Total pigments & $\begin{array}{l}\text { IAA } \\
(\mu \mathrm{g} / \\
g \\
\mathrm{FW})\end{array}$ & $\begin{array}{l}\text { Phenolic } \\
\text { content } \\
\text { (mg/100 } \\
\mathrm{g} \mathrm{FW)}\end{array}$ \\
\hline \multirow[t]{3}{*}{ Blanka } & Benzoic a & 1.726 & 0.598 & 0.540 & 2.864 & 43.19 & 91.55 \\
\hline & T-cinnamic & 1.498 & 0.503 & 0.499 & 2.500 & 49.52 & 104.98 \\
\hline & Salicylic & 1.751 & 0.747 & 0.557 & 3.055 & 50.61 & 107.29 \\
\hline \multirow[t]{3}{*}{ Line-4 } & Benzoic & 1.434 & 0.486 & 0.464 & 2.383 & 28.43 & 60.27 \\
\hline & T-cinnamic & 1.507 & 0.667 & 0.482 & 2.657 & 39.64 & 84.04 \\
\hline & Salicylic & 1.562 & 0.575 & 0.517 & 2.653 & 30.54 & 64.75 \\
\hline \multirow[t]{3}{*}{ Giza-8 } & Benzoic & 1.378 & 0.557 & 0.392 & 2.326 & 37.68 & 79.88 \\
\hline & T-cinnamic & 1.326 & 0.563 & 0.426 & 2.316 & 54.31 & 115.14 \\
\hline & Salicylic & 1.391 & 0.572 & 0.438 & 2.401 & 53.37 & 113.14 \\
\hline LSD 0.05 & & 0.11 & 0.05 & 0.03 & 0.13 & 1.21 & 2.15 \\
\hline
\end{tabular}




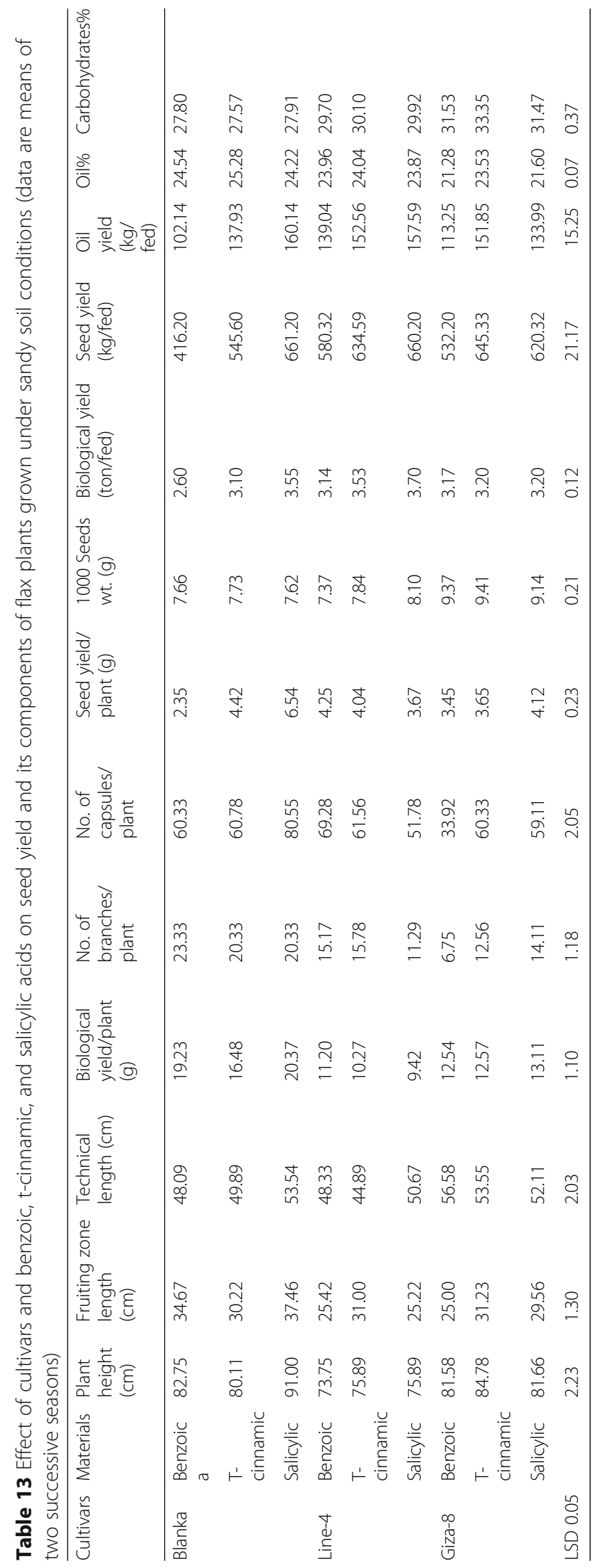


Table 14 Effect of cultivars and phenolic acid concentrations on growth parameters of flax plants grown under sandy soil conditions (data are means of two successive seasons)

\begin{tabular}{lllllllll}
\hline Cultivars & $\begin{array}{l}\text { Concentrations } \\
\mathrm{mg} / \mathrm{l}\end{array}$ & $\begin{array}{l}\text { Shoot length } \\
(\mathrm{cm})\end{array}$ & $\begin{array}{l}\text { No. of basal } \\
\text { branches }\end{array}$ & $\begin{array}{l}\text { Shoot fresh wt/ } \\
\text { plant (g) }\end{array}$ & $\begin{array}{l}\text { Shoot dry wt/ } \\
\text { plant (g) }\end{array}$ & $\begin{array}{l}\text { Root length } \\
(\mathrm{cm})\end{array}$ & $\begin{array}{l}\text { Root fresh wt/ } \\
\text { plant (g) }\end{array}$ & $\begin{array}{l}\text { Root dry wt/ } \\
\text { plant (g) }\end{array}$ \\
\hline Blanka & Control & 48.00 & 1.67 & 6.90 & 0.79 & 6.00 & 0.88 & 0.15 \\
& 50 & 62.00 & 2.56 & 9.50 & 1.04 & 12.17 & 1.25 & 0.25 \\
& 75 & 66.11 & 3.11 & 10.48 & 1.12 & 13.00 & 1.21 & 0.27 \\
& 100 & 62.11 & 2.78 & 10.67 & 0.93 & 12.28 & 1.42 & 0.23 \\
Line-4 & Control & 38.33 & 2.00 & 3.30 & 0.40 & 9.67 & 0.52 & 0.05 \\
& 50 & 50.45 & 2.89 & 5.11 & 0.49 & 12.06 & 0.65 & 0.10 \\
& 75 & 53.33 & 3.45 & 5.84 & 0.67 & 12.89 & 0.72 & 0.14 \\
& 100 & 57.89 & 2.78 & 6.21 & 0.71 & 13.33 & 0.88 & 0.14 \\
Giza-8 & Control & 46.00 & 1.00 & 4.60 & 0.51 & 8.67 & 0.61 & 0.07 \\
& 50 & 58.11 & 1.33 & 6.34 & 0.75 & 12.44 & 0.83 & 0.91 \\
& 75 & 67.67 & 2.03 & 8.74 & 0.94 & 14.66 & 1.19 & 1.00 \\
LSD 0.05 & 70.33 & 2.33 & 9.00 & 1.00 & 13.33 & 1.41 & 0.19 \\
\hline
\end{tabular}

acid at $100 \mathrm{mg} / \mathrm{l}$ was the most effective treatment on photosynthetic pigments. In addition, t-cinnamic at 75 $\mathrm{mg} / \mathrm{l}$ was the most effective treatment on chlorophyll a, carotenoids, and total pigments of cultivar Giza-8. While $100 \mathrm{mg} / \mathrm{l}$ salicylic acid was the most effective treatment on chlorophyll b compared with control plants.

Data in Table 22 indicate that there are significant effects of all interactions between flax cultivars (Blanka, Line-4, and Giza-8) and benzoic, t-cinnamic, and salicylic acids at different concentrations. Results indicate that the highest seed yield (15.83 g/plant), biological yield (4.05 ton/fed), number of capsules/ plant (89.33), and tallest plants $(93.33 \mathrm{~cm})$ were obtained at $100 \mathrm{mg} / \mathrm{l}$ salicylic acid with blanka cultivar. Meanwhile, benzoic acid at $75 \mathrm{mg} / \mathrm{l}$ gave the highest increments in biological yield/plant $(29.40 \mathrm{~g})$, number of fruiting branches/plant (34.33), fruiting zone length $(41.33 \mathrm{~cm})$, and oil seed (\% 27.14) of blanka cultivar, whereas benzoic acid at $50 \mathrm{mg} / \mathrm{l}$ with Giza-8 cultivar recorded the highest technical length $(59.00 \mathrm{~cm})$. The heaviest 1000 seeds (10.09) recorded by interaction of Giza- 8 with benzoic acid at $75 \mathrm{mg} / \mathrm{l}$. The highest seed yield $(741.6 \mathrm{~kg} / \mathrm{fed})$ recorded by giza- 8 and $100 \mathrm{mg} / \mathrm{l}$ salicylic acid; finally, treatment of the interaction

Table 15 Effect of cultivars and phenolic acid concentrations on photosynthetic pigments, IAA, and phenolic content of flax plants grown under sandy soil conditions (data are means of two successive seasons)

\begin{tabular}{|c|c|c|c|c|c|c|c|}
\hline Cultivars & $\begin{array}{l}\text { Concentrations } \\
(\mathrm{mg} / \mathrm{l})\end{array}$ & $\begin{array}{l}\text { Chlorophyll a } \\
\text { (mg/g FW) }\end{array}$ & Chlorophyll b & Carotenoids & Total pigments & $\begin{array}{l}\text { IAA } \\
(\mu g / \\
g \\
\text { FW) }\end{array}$ & $\begin{array}{l}\text { Phenolic } \\
\text { content } \\
\text { (mg/100 } \\
\text { g FW) }\end{array}$ \\
\hline \multirow[t]{4}{*}{ Blanka } & Control & 1.31 & 0.43 & 0.42 & 2.16 & 27.67 & 58.65 \\
\hline & 50 & 1.58 & 0.56 & 0.52 & 2.65 & 42.84 & 90.82 \\
\hline & 75 & 1.68 & 0.66 & 0.55 & 2.89 & 51.08 & 108.07 \\
\hline & 100 & 1.86 & 0.69 & 0.57 & 3.11 & 54.57 & 115.90 \\
\hline \multirow[t]{4}{*}{ Line-4 } & Control & 1.26 & 0.46 & 0.41 & 2.13 & 18.50 & 39.22 \\
\hline & 50 & 1.39 & 0.54 & 0.42 & 2.36 & 26.56 & 56.30 \\
\hline & 75 & 1.56 & 0.55 & 0.49 & 2.60 & 35.72 & 75.72 \\
\hline & 100 & 1.60 & 0.65 & 0.57 & 2.82 & 39.65 & 84.05 \\
\hline \multirow[t]{4}{*}{ Giza-8 } & Control & 1.01 & 0.44 & 0.35 & 1.80 & 24.25 & 51.41 \\
\hline & 50 & 1.45 & 0.55 & 0.39 & 2.38 & 37.81 & 80.16 \\
\hline & 75 & 1.44 & 0.60 & 0.46 & 2.51 & 52.68 & 111.69 \\
\hline & 100 & 1.33 & 0.58 & 0.42 & 2.33 & 59.34 & 125.80 \\
\hline LSD 0.05 & & 0.05 & 0.13 & 0.11 & 0.17 & 1.30 & 3.85 \\
\hline
\end{tabular}


Table 16 Effect of cultivars and phenolic acid concentrations on seed yield and its components of flax plants grown under sandy soil conditions (data are means of two successive seasons)

\begin{tabular}{|c|c|c|c|c|c|c|c|c|c|c|c|c|c|}
\hline Cultivars & $\begin{array}{l}\text { Conc } \\
\mathrm{mg} / \mathrm{l}\end{array}$ & $\begin{array}{l}\text { Plant } \\
\text { height } \\
(\mathrm{cm})\end{array}$ & $\begin{array}{l}\text { Fruiting } \\
\text { zone } \\
\text { length } \\
(\mathrm{cm})\end{array}$ & $\begin{array}{l}\text { Technical } \\
\text { length } \\
(\mathrm{cm})\end{array}$ & $\begin{array}{l}\text { Biol. } \\
\text { yield/ } \\
\text { plant } \\
\text { (g) }\end{array}$ & $\begin{array}{l}\text { No. of } \\
\text { branches/ } \\
\text { plant }\end{array}$ & $\begin{array}{l}\text { No. of } \\
\text { capsules/ } \\
\text { plant }\end{array}$ & $\begin{array}{l}\text { Seed } \\
\text { yield/ } \\
\text { plant (g) }\end{array}$ & $\begin{array}{l}1000 \\
\text { Seeds } \\
\text { wt. (g) }\end{array}$ & $\begin{array}{l}\text { Biol. } \\
\text { yield } \\
\text { (ton/fed) }\end{array}$ & $\begin{array}{l}\text { Seed } \\
\text { yield } \\
\text { (kg/fed) }\end{array}$ & Oil\% & Carbohydrates\% \\
\hline \multirow[t]{4}{*}{ Blanka } & 0.0 & 71.67 & 25.67 & 46.00 & 9.93 & 15.67 & 43.33 & 3.24 & 5.95 & 1.840 & 304.00 & 22.54 & 25.50 \\
\hline & 50 & 84.11 & 33.89 & 50.22 & 15.51 & 17.00 & 60.11 & 4.52 & 7.30 & 2.453 & 463.73 & 24.30 & 27.08 \\
\hline & 75 & 89.11 & 36.68 & 52.43 & 23.38 & 28.00 & 73.22 & 5.65 & 8.48 & 3.810 & 630.13 & 26.00 & 28.81 \\
\hline & 100 & 84.33 & 34.77 & 49.56 & 20.29 & 21.55 & 74.00 & 4.24 & 7.80 & 3.233 & 566.53 & 24.40 & 28.15 \\
\hline \multirow[t]{4}{*}{ Line-4 } & 0.0 & 61.33 & 23.00 & 38.33 & 6.80 & 11.33 & 44.33 & 4.25 & 6.28 & 2.630 & 478.40 & 21.62 & 28.04 \\
\hline & 50 & 71.45 & 24.67 & 46.78 & 9.30 & 11.40 & 53.67 & 5.65 & 7.28 & 3.053 & 577.12 & 23.16 & 29.76 \\
\hline & 75 & 79.33 & 29.78 & 49.55 & 13.20 & 17.33 & 70.04 & 5.62 & 8.25 & 3.787 & 658.33 & 25.03 & 30.61 \\
\hline & 100 & 78.89 & 28.00 & 50.89 & 9.84 & 14.78 & 67.22 & 5.12 & 8.15 & 3.697 & 673.63 & 24.46 & 29.90 \\
\hline \multirow[t]{4}{*}{ Giza-8 } & 0.0 & 71.33 & 20.67 & 50.66 & 6.47 & 5.67 & 13.33 & 4.12 & 8.10 & 1.960 & 391.20 & 19.42 & 28.43 \\
\hline & 50 & 80.44 & 25.22 & 55.23 & 9.83 & 6.45 & 33.67 & 6.24 & 8.74 & 2.863 & 530.80 & 21.21 & 32.11 \\
\hline & 75 & 84.89 & 30.90 & 53.98 & 16.23 & 14.22 & 63.11 & 7.13 & 9.91 & 3.433 & 658.45 & 22.95 & 32.68 \\
\hline & 100 & 86.11 & 31.11 & 55.00 & 14.17 & 13.11 & 63.44 & 7.32 & 9.69 & 3.683 & 655.60 & 22.87 & 32.59 \\
\hline LSD 0.05 & & 2.05 & 1.15 & 2.25 & 1.33 & 1.50 & 3.25 & 0.25 & 0.04 & 0.310 & 30.10 & 0.21 & 0.25 \\
\hline
\end{tabular}

between benzoic acid $100 \mathrm{mg} / \mathrm{l}$ with Giza-8 gave the highest carbohydrates $33.67 \%$.

\section{Discussion}

The collected data demonstrated the significant effect of cultivars on different growth parameters (shoot and root length $(\mathrm{cm})$, number of basal branches/plant, fresh and dry weight of shoot and root (g)) (Table 2) and photosynthetic pigments (chlorophyll a, chlorophyll b, carotenoids and total pigments) (Table 3) as well as seed yield, its components, oil\%, and carbohydrate\% of the three tested cultivars (Table 4). The superiority of Blanka cultivar on yield and its components might be due to the highest values of photosynthetic pigments (chlorophyll a, chlorophyll b, carotenoids, and consequently total pigments). These increases might be due to the increased rate of quenching of chlorophyll fluorescence, which markedly increased plant biomass, and this steady state was greater than the other two cultivars. Moreover, the superiority of this cultivar might be due to the superiority in plant height, fruiting zone length, branches and capsules number/plant, seed yield/plant. These obtained results were in accordance with those obtained by Dubey (2001), Kineber and El-Sayed (2004), Kineber et al. (2006), Khalifa et al. (2011), Afifi et al. (2014) and Bakhoum et al. (2019) in many regions of growing flax in the world. The presence of

Table 17 Effect of benzoic, t-cinnamic, and salicylic acids levels on growth parameters of flax plants grown under sandy soil conditions (data are means of two successive seasons)

\begin{tabular}{|c|c|c|c|c|c|c|c|c|}
\hline Treatments & & $\begin{array}{l}\text { Shoot length } \\
(\mathrm{cm})\end{array}$ & $\begin{array}{l}\text { No. of basal } \\
\text { branches }\end{array}$ & $\begin{array}{l}\text { Shoot fresh wt/ } \\
\text { plant (g) }\end{array}$ & $\begin{array}{l}\text { Shoot dry wt/ } \\
\text { plant (g) }\end{array}$ & $\begin{array}{l}\text { Root length } \\
(\mathrm{cm})\end{array}$ & $\begin{array}{l}\text { Root fresh wt/ } \\
\text { plant (g) }\end{array}$ & $\begin{array}{l}\text { Root dry wt/ } \\
\text { plant (g) }\end{array}$ \\
\hline Control & & 44.11 & 1.56 & 4.93 & 0.57 & 8.11 & 0.67 & 0.09 \\
\hline \multirow{3}{*}{$\begin{array}{l}\text { Benzoic } \\
\text { acid }\end{array}$} & 50 & 57.45 & 2.00 & 7.31 & 0.79 & 11.61 & 1.02 & 0.33 \\
\hline & 75 & 66.22 & 2.33 & 9.16 & 1.04 & 13.22 & 1.37 & 0.40 \\
\hline & 100 & 60.56 & 2.33 & 7.85 & 0.87 & 12.55 & 1.35 & 0.35 \\
\hline \multirow{3}{*}{$\begin{array}{l}\text { T-cinnamic } \\
\text { acid }\end{array}$} & 50 & 56.44 & 2.56 & 7.33 & 0.82 & 13.22 & 0.78 & 0.16 \\
\hline & 75 & 65.00 & 2.67 & 8.94 & 0.91 & 14.78 & 1.23 & 0.20 \\
\hline & 100 & 62.00 & 2.22 & 8.93 & 0.73 & 11.83 & 1.02 & 0.13 \\
\hline \multirow{3}{*}{$\begin{array}{l}\text { Salicylic } \\
\text { acid }\end{array}$} & 50 & 56.89 & 2.11 & 6.70 & 0.70 & 12.50 & 0.94 & 0.15 \\
\hline & 75 & 59.89 & 2.22 & 7.76 & 0.82 & 12.55 & 0.92 & 0.14 \\
\hline & 100 & 64.78 & 2.33 & 9.10 & 1.00 & 14.56 & 1.13 & 0.29 \\
\hline LSD 0.05 & & 2.78 & 0.15 & 0.35 & 0.11 & 0.41 & 0.16 & 0.05 \\
\hline
\end{tabular}


Table 18 Effect of benzoic, t-cinnamic, and salicylic acids levels on some biochemical constituents of flax plants grown under sandy soil conditions (data are means of two successive seasons)

\begin{tabular}{|c|c|c|c|c|c|c|c|}
\hline \multicolumn{2}{|l|}{ Treatments } & \multirow{2}{*}{$\begin{array}{l}\text { Chlorophyll a (mg/g } \\
\text { FW) } \\
1.192\end{array}$} & \multirow{2}{*}{$\begin{array}{l}\text { Chlorophyll b (mg/g } \\
\text { FW) } \\
0.445\end{array}$} & \multirow{2}{*}{$\begin{array}{l}\text { Carotenoids (mg/g } \\
\text { FW) } \\
0.391\end{array}$} & \multirow{2}{*}{$\begin{array}{l}\text { Total pigments (mg/ } \\
\text { g FW) } \\
2.028\end{array}$} & \multirow{2}{*}{$\begin{array}{l}\text { IAA }(\mu \mathrm{g} / \mathrm{g} \\
\mathrm{FW}) \\
23.47\end{array}$} & \multirow{2}{*}{$\begin{array}{l}\text { Phenolic content }(\mathrm{mg} / 100 \\
\text { g FW) } \\
49.76\end{array}$} \\
\hline Control & & & & & & & \\
\hline \multirow[t]{3}{*}{ Benzoic acid } & 50 & 1.585 & 0.556 & 0.448 & 2.589 & 34.79 & 73.74 \\
\hline & 75 & 1.679 & 0.595 & 0.528 & 2.802 & 46.23 & 97.41 \\
\hline & 100 & 1.594 & 0.591 & 0.493 & 2.678 & 41.23 & 88.00 \\
\hline \multirow{3}{*}{$\begin{array}{l}\text { T-cinnamic } \\
\text { acid }\end{array}$} & 50 & 1.473 & 0.532 & 0.461 & 2.466 & 34.82 & 73.82 \\
\hline & 75 & 1.545 & 0.560 & 0.529 & 2.634 & 50.83 & 107.41 \\
\hline & 100 & 1.529 & 0.589 & 0.500 & 2.617 & 47.77 & 101.64 \\
\hline \multirow[t]{3}{*}{ Salicylic acid } & 50 & 1.460 & 0.589 & 0.450 & 2.500 & 37.60 & 79.71 \\
\hline & 75 & 1.458 & 0.652 & 0.451 & 2.562 & 51.41 & 108.99 \\
\hline & 100 & 1.666 & 0.737 & 0.564 & 2.967 & 55.55 & 117.77 \\
\hline LSD at 0.05 & & 0.10 & 0.103 & 0.10 & 0.113 & 1.22 & 2.65 \\
\hline
\end{tabular}

variability among Blanka, Line-4, and Giza-8 cultivars might be expected due to the difference of these cultivars in origin, growth habit, the high diversity in genetic constituent, and the environmental conditions of investigated cultivars under sandy soils (Bakhoum et al. 2019).

Regarding the positive effect of benzoic, $\mathrm{t}$-cinnamic, and salicylic acids on growth parameters, some biochemical constituents, seed yield, and its components of three flax cultivars, it is clear that the obtained data were in good agreement with those obtained by Abd ElHamid and Sadak (2012), Bakry et al. (2012) and Dawood et al. (2012) using salicylic acid on flax and sunflower plants, Sadak et al. (2013) using benzoic and salicylic acids on soybean plant, Talaat et al. (2014) using benzoic, t-cinnamic and salicylic acids on khella plant, Sadak et al. (2015) using t-cinnamic acid on roselle plant, El-Awadi et al. (2016) using t-cinnamic, and benzoic acids on lupine plant and Abd elkader et al. (2018) using salicylic acid on Nigella sativa plant. Crop productivity improvement by exogenous treatment with some effective growth regulators was an effective technique. Salicylic acid and its precursor's benzoic acid and tcinnamic acids had been reported to induce significant effects on various biochemical aspects of plant. The effect of these compounds was through enhancing certain processes and inhibiting others (Raskin 1992). The enhancement effect of benzoic, $t$-cinnamic, and salicylic acid on growth criteria might be attributed to the enhancement effect of these compounds on photosynthesizing tissue. Moreover, the increases in dry weight of flax plant could be due to the increases in shoot length and number of branches/plant that led to increases in photosynthetic processes. In addition, the stimulatory

Table 19 Effect of benzoic, t-cinnamic and salicylic acids on seed yield, biological yield and its related characters of flax plants grown under sandy soil conditions (data are means of two successive seasons)

\begin{tabular}{|c|c|c|c|c|c|c|c|c|c|c|c|c|c|c|}
\hline \multicolumn{2}{|c|}{ Treatments } & $\begin{array}{l}\text { Plant } \\
\text { height } \\
\text { (cm) }\end{array}$ & $\begin{array}{l}\text { Fruiting } \\
\text { zone } \\
\text { length } \\
(\mathrm{cm})\end{array}$ & $\begin{array}{l}\text { Technical } \\
\text { length } \\
\text { (cm) }\end{array}$ & $\begin{array}{l}\text { Biol. } \\
\text { yield/ } \\
\text { plant } \\
\text { (g) }\end{array}$ & $\begin{array}{l}\text { No. of } \\
\text { branches/ } \\
\text { plant }\end{array}$ & $\begin{array}{l}\text { No. of } \\
\text { capsules/ } \\
\text { plant }\end{array}$ & $\begin{array}{l}\text { Seed } \\
\text { yield/ } \\
\text { plant (g) }\end{array}$ & $\begin{array}{l}1000 \\
\text { Seeds } \\
\text { wt. (g) }\end{array}$ & $\begin{array}{l}\text { Biol. } \\
\text { yield } \\
\text { (ton/ } \\
\text { fed) }\end{array}$ & $\begin{array}{l}\text { Seed } \\
\text { yield } \\
\text { (kg/fed) }\end{array}$ & $\begin{array}{l}\text { Seed } \\
\text { yield } \\
\text { (kg/fed) }\end{array}$ & Oil\% & $\begin{array}{l}\text { Carbo } \\
\%\end{array}$ \\
\hline \multicolumn{2}{|l|}{ Control } & 68.11 & 22.78 & 45.33 & 5.73 & 10.89 & 33.66 & 1.85 & 6.78 & 2.143 & 391.20 & 82.90 & 21.19 & 27.32 \\
\hline \multirow{3}{*}{$\begin{array}{l}\text { Benzoic } \\
\text { acid }\end{array}$} & 50 & 79.56 & 25.45 & 54.11 & 12.49 & 13.89 & 52.78 & 2.72 & 7.76 & 2.693 & 475.20 & 107.35 & 22.59 & 29.52 \\
\hline & 75 & 87.11 & 33.67 & 53.44 & 17.01 & 20.78 & 101.70 & 5.55 & 9.45 & 3.683 & 627.73 & 157.50 & 25.09 & 30.93 \\
\hline & 100 & 82.67 & 29.67 & 53.00 & 12.05 & 14.78 & 90.55 & 4.21 & 8.55 & 3.353 & 544.16 & 131.36 & 24.14 & 30.93 \\
\hline \multirow{3}{*}{$\begin{array}{l}\text { t- } \\
\text { Cinnamic } \\
\text { acid }\end{array}$} & 50 & 74.44 & 27.33 & 47.11 & 6.59 & 9.29 & 37.33 & 2.10 & 8.00 & 2.767 & 543.07 & 124.31 & 22.89 & 29.24 \\
\hline & 75 & 87.22 & 35.22 & 52.00 & 16.48 & 21.00 & 91.00 & 5.15 & 8.67 & 3.853 & 655.19 & 160.78 & 24.54 & 30.32 \\
\hline & 100 & 78.00 & 30.78 & 47.22 & 12.61 & 15.44 & 78.33 & 3.72 & 8.29 & 3.380 & 627.87 & 77.29 & 12.31 & 29.40 \\
\hline \multirow{3}{*}{$\begin{array}{l}\text { Salicylic } \\
\text { acid }\end{array}$} & 50 & 80.67 & 29.33 & 51.34 & 11.90 & 11.67 & 57.33 & 3.27 & 7.55 & 2.910 & 553.39 & 128.22 & 23.17 & 30.19 \\
\hline & 75 & 82.33 & 33.55 & 48.78 & 15.32 & 17.78 & 92.00 & 4.14 & 8.52 & 3.493 & 664.00 & 81.94 & 12.34 & 30.85 \\
\hline & 100 & 88.66 & 36.89 & 51.77 & 15.98 & 19.22 & 79.78 & 6.09 & 8.81 & 3.880 & 723.73 & 175.72 & 24.28 & 30.31 \\
\hline \multicolumn{2}{|l|}{ LSD 0.05} & 3.15 & 2.55 & 3.05 & 0.37 & 2.17 & 4.15 & 0.18 & 0.13 & 0.330 & 22.17 & 7.53 & 0.34 & 0.38 \\
\hline
\end{tabular}


Table 20 Effect of interaction between benzoic, t-cinnamic, and salicylic acids on growth parameters of flax varieties grown under sandy soil conditions (data are means of two successive seasons)

\begin{tabular}{|c|c|c|c|c|c|c|c|c|c|}
\hline Cultivars & $\begin{array}{l}\text { Treatments } \\
\text { L) }\end{array}$ & & $\begin{array}{l}\text { Shoot length } \\
(\mathrm{cm})\end{array}$ & $\begin{array}{l}\text { No. of basal } \\
\text { branches }\end{array}$ & $\begin{array}{l}\text { Shoot fresh wt/ } \\
\text { plant (g) }\end{array}$ & $\begin{array}{l}\text { Shoot dry wt/ } \\
\text { plant (g) }\end{array}$ & $\begin{array}{l}\text { Root length } \\
(\mathrm{cm})\end{array}$ & $\begin{array}{l}\text { Root fresh wt/ } \\
\text { plant (g) }\end{array}$ & $\begin{array}{l}\text { Root dry wt/ } \\
\text { plant (g) }\end{array}$ \\
\hline \multirow[t]{10}{*}{ Blanka } & Control & & 48.00 & 1.67 & 6.90 & 0.79 & 6.00 & 0.88 & 0.15 \\
\hline & \multirow{3}{*}{$\begin{array}{l}\text { Benzoic } \\
\text { acid }\end{array}$} & 50 & 63.67 & 3.00 & 10.13 & 1.08 & 8.00 & 1.08 & 0.23 \\
\hline & & 75 & 66.33 & 4.33 & 11.02 & 1.15 & 10.33 & 1.36 & 0.25 \\
\hline & & 100 & 61.67 & 3.00 & 9.00 & 0.96 & 12.00 & 1.68 & 0.29 \\
\hline & \multirow{3}{*}{$\begin{array}{l}\text { T-cinnamic } \\
\text { acid }\end{array}$} & 50 & 61.00 & 3.67 & 9.15 & 0.98 & 13.00 & 1.00 & 0.26 \\
\hline & & 75 & 69.00 & 3.33 & 11.05 & 1.22 & 16.33 & 1.14 & 0.38 \\
\hline & & 100 & 56.33 & 1.67 & 10.78 & 0.49 & 10.50 & 1.38 & 0.16 \\
\hline & \multirow{3}{*}{$\begin{array}{l}\text { Salicylic } \\
\text { acid }\end{array}$} & 50 & 61.33 & 1.00 & 9.21 & 1.05 & 15.50 & 1.66 & 0.27 \\
\hline & & 75 & 63.00 & 1.67 & 9.36 & 0.98 & 12.33 & 1.13 & 0.17 \\
\hline & & 100 & 68.33 & 3.67 & 12.23 & 1.35 & 14.33 & 1.19 & 0.24 \\
\hline \multirow[t]{10}{*}{ Line-4 } & \multicolumn{2}{|l|}{ Control } & 38.33 & 2.00 & 3.30 & 0.40 & 9.67 & 0.52 & 0.05 \\
\hline & \multirow{3}{*}{$\begin{array}{l}\text { Benzoic } \\
\text { acid }\end{array}$} & 50 & 50.00 & 2.67 & 4.49 & 0.44 & 14.50 & 0.85 & 0.11 \\
\hline & & 75 & 53.67 & 2.67 & 5.58 & 0.70 & 15.00 & 0.94 & 0.16 \\
\hline & & 100 & 54.67 & 2.67 & 4.83 & 0.54 & 13.33 & 0.89 & 0.15 \\
\hline & \multirow{3}{*}{$\begin{array}{l}\text { T-cinnamic } \\
\text { acid }\end{array}$} & 50 & 48.67 & 3.00 & 4.60 & 0.55 & 11.67 & 0.58 & 0.11 \\
\hline & & 75 & 49.33 & 3.00 & 5.75 & 0.66 & 13.67 & 0.60 & 0.12 \\
\hline & & 100 & 60.00 & 2.67 & 6.82 & 0.76 & 14.00 & 0.79 & 0.12 \\
\hline & \multirow{3}{*}{$\begin{array}{l}\text { Salicylic } \\
\text { acid }\end{array}$} & 50 & 52.67 & 3.00 & 6.24 & 0.49 & 10.00 & 0.53 & 0.09 \\
\hline & & 75 & 57.00 & 4.67 & 6.20 & 0.64 & 10.00 & 0.62 & 0.13 \\
\hline & & 100 & 59.00 & 3.00 & 6.97 & 0.83 & 12.67 & 0.95 & 0.16 \\
\hline \multirow[t]{10}{*}{ Giza-8 } & \multicolumn{2}{|l|}{ Control } & 46.00 & 1.00 & 4.60 & 0.51 & 8.67 & 0.61 & 0.07 \\
\hline & \multirow{3}{*}{$\begin{array}{l}\text { Benzoic } \\
\text { acid }\end{array}$} & 50 & 58.67 & 1.67 & 7.30 & 0.85 & 12.33 & 1.13 & 0.64 \\
\hline & & 75 & 75.67 & 2.76 & 10.87 & 1.14 & 14.33 & 1.52 & 0.80 \\
\hline & & 100 & 65.33 & 2.33 & 9.72 & 1.11 & 12.33 & 1.47 & 0.60 \\
\hline & \multirow{3}{*}{$\begin{array}{l}\text { T-cinnamic } \\
\text { acid }\end{array}$} & 50 & 59.00 & 1.00 & 7.09 & 0.82 & 13.00 & 0.74 & 1.10 \\
\hline & & 75 & 67.67 & 1.67 & 7.62 & 0.85 & 14.33 & 1.04 & 1.10 \\
\hline & & 100 & 72.67 & 2.33 & 9.19 & 0.95 & 11.00 & 1.49 & 1.12 \\
\hline & \multirow{3}{*}{$\begin{array}{l}\text { Salicylic } \\
\text { acid }\end{array}$} & 50 & 56.67 & 1.33 & 4.64 & 0.57 & 12.00 & 0.63 & 0.98 \\
\hline & & 75 & 59.67 & 1.67 & 7.73 & 0.84 & 15.33 & 1.01 & 1.11 \\
\hline & & 100 & 73.00 & 2.33 & 8.09 & 0.93 & 16.67 & 1.26 & 1.06 \\
\hline \multicolumn{3}{|l|}{ LSD 0.05} & 3.03 & 0.21 & 0.37 & 0.18 & 0.62 & 0.12 & 0.03 \\
\hline
\end{tabular}

effects of salicylic acid and its precursor's benzoic and tcinnamic acids on different studied growth criteria might be due to the bioregulator effects on different biochemical and physiological processes in plants like ion uptake, cell elongation, cell differentiation, sink/source regulation, activities of different enzymes, photosynthetic pigments, and protein synthesis (Blokhina et al. 2003). The increases in photosynthetic pigment contents of the three tested flax cultivars might be due to the enhancement in its synthesis and/or retardation of pigment degradation (Bakry et al. 2012). In addition, the potent effects of particularly salicylic acid and its precursors' benzoic acid and $\mathrm{t}$-cinnamic acid could be ascribed to the reduction in chlorophyll loss due to its ability to increase the antioxidant capacity of the plants or inducing the synthesis of stabilizing substances ( $\mathrm{Ne}^{\prime}$ meth et al. 2008). In addition, the enhancing effects of different treatments on photosynthetic capacity could be attributed to its stimulatory effects on Rubisco activity and pigment contents (Szepesi et al. 2005) and $\mathrm{CO}_{2}$ assimilation, rate of photosynthesis, and mineral uptake increments (Bakry et al. 2012). The increases in IAA as a plant growth regulator in response to different treatments might be attributed to the increases in its biosynthesis and/or decreases in its degradation and conjugation. The increases in phenolic contents in plants 
Table 21 Effect of interaction between benzoic, t-cinnamic and salicylic acids on photosynthetic pigments, IAA and phenolic contents of flax cultivars grown under sandy soil conditions (data are means of two successive seasons)

\begin{tabular}{|c|c|c|c|c|c|c|c|c|}
\hline Cultivars & $\begin{array}{l}\text { Treatments } \\
(\mathrm{mg} / \mathrm{L})\end{array}$ & & $\begin{array}{l}\text { Chlorophyll a } \\
\text { (mg/g FW) }\end{array}$ & Chlorophyll b & Carotenoids & Total pigments & $\begin{array}{l}\text { IAA } \\
(\mu \mathrm{g} / \\
\mathrm{g} \\
\mathrm{FW})\end{array}$ & $\begin{array}{l}\text { Phenolic } \\
\text { content(mg/ } \\
100 \mathrm{~g} \mathrm{FW})\end{array}$ \\
\hline \multirow[t]{10}{*}{ Blanka } & Control & & 1.313 & 0.433 & 0.415 & 2.161 & 27.67 & 58.65 \\
\hline & Benzoic acid & 50 & 1.653 & 0.591 & 0.550 & 2.794 & 43.75 & 92.75 \\
\hline & & 75 & 1.988 & 0.662 & 0.641 & 3.291 & 48.02 & 101.79 \\
\hline & & 100 & 1.950 & 0.704 & 0.555 & 3.209 & 53.30 & 113.00 \\
\hline & T-cinnamic acid & 50 & 1.381 & 0.491 & 0.453 & 2.325 & 42.42 & 89.92 \\
\hline & & 75 & 1.406 & 0.514 & 0.477 & 2.396 & 51.75 & 109.71 \\
\hline & & 100 & 1.707 & 0.504 & 0.568 & 2.779 & 54.39 & 115.30 \\
\hline & Salicylic acid & 50 & 1.711 & 0.584 & 0.543 & 2.838 & 42.35 & 89.78 \\
\hline & & 75 & 1.632 & 0.807 & 0.545 & 2.985 & 53.47 & 112.71 \\
\hline & & 100 & 1.910 & 0.850 & 0.583 & 3.343 & 56.02 & 119.39 \\
\hline \multirow[t]{10}{*}{ Line-4 } & Control & & 1.257 & 0.462 & 0.407 & 2.126 & 18.50 & 39.22 \\
\hline & Benzoic acid & 50 & 1.541 & 0.489 & 0.506 & 2.536 & 25.36 & 53.76 \\
\hline & & 75 & 1.602 & 0.537 & 0.492 & 2.631 & 35.44 & 75.12 \\
\hline & & 100 & 1.334 & 0.457 & 0.449 & 2.240 & 34.42 & 72.96 \\
\hline & T-cinnamic acid & 50 & 1.326 & 0.481 & 0.425 & 2.232 & 24.75 & 52.47 \\
\hline & & 75 & 1.616 & 0.573 & 0.534 & 2.723 & 30.75 & 65.19 \\
\hline & & 100 & 1.743 & 0.671 & 0.591 & 3.004 & 36.13 & 76.60 \\
\hline & Salicylic acid & 50 & 1.316 & 0.649 & 0.337 & 2.303 & 29.56 & 62.67 \\
\hline & & 75 & 1.473 & 0.530 & 0.443 & 2.447 & 40.97 & 86.85 \\
\hline & & 100 & 1.733 & 0.823 & 0.666 & 3.222 & 48.40 & 102.60 \\
\hline \multirow[t]{10}{*}{ Giza-8 } & Control & & 1.006 & 0.439 & 0.351 & 1.796 & 24.25 & 51.41 \\
\hline & Benzoic acid & 50 & 1.560 & 0.589 & 0.289 & 2.438 & 35.25 & 74.72 \\
\hline & & 75 & 1.447 & 0.585 & 0.452 & 2.484 & 40.25 & 85.33 \\
\hline & & 100 & 1.498 & 0.613 & 0.475 & 2.585 & 50.97 & 108.05 \\
\hline & T-cinnamic acid & 50 & 1.422 & 0.531 & 0.397 & 2.351 & 37.30 & 79.08 \\
\hline & & 75 & 1.614 & 0.593 & 0.576 & 2.783 & 61.00 & 129.32 \\
\hline & & 100 & 1.137 & 0.593 & 0.340 & 2.069 & 61.80 & 131.02 \\
\hline & Salicylic acid & 50 & 1.354 & 0.535 & 0.470 & 2.359 & 40.89 & 86.68 \\
\hline & & 75 & 1.269 & 0.618 & 0.365 & 2.253 & 56.80 & 120.42 \\
\hline & & 100 & 1.356 & 0.537 & 0.443 & 2.335 & 65.25 & 138.33 \\
\hline LSD 0.05 & & & 0.11 & 0.071 & 0.053 & 0.125 & 2.23 & 4.72 \\
\hline
\end{tabular}

treated with different concentrations of benzoic, $\mathrm{t}$ cinnamic, and salicylic acid might be due to the phenolic nature of these compounds (Sadak et al. 2013). Therefore, it could be expected that their application on plants increased phenolic concentration as previously mentioned by Bakry et al. (2012) on linseed, Sadak et al. (2013) on soybean, and El-Awadi et al. (2016) on lupine plant. These increases in total phenolic content might be due to the increase in the synthesis of carbohydrate (Sadak et al. 2013). In addition, Bakry et al. (2012) showed that the increase in total phenolic contents was agreed with the increase in IAA contents and led to the suggestion that most of phenolic compounds are diphenols and polyphenols which may inhibit IAA oxidase activity and leading to auxin accumulation and reflected in stimulating the growth and yield of plant. The increases in seed yield and its components could be resulted from the effect of different treatments on growth and development, and these might be due to the increase in growth, photosynthetic pigment contents that might lead to increases in the photosynthesis process resulting in greater transfer of photo-assimilates to seeds and causing 


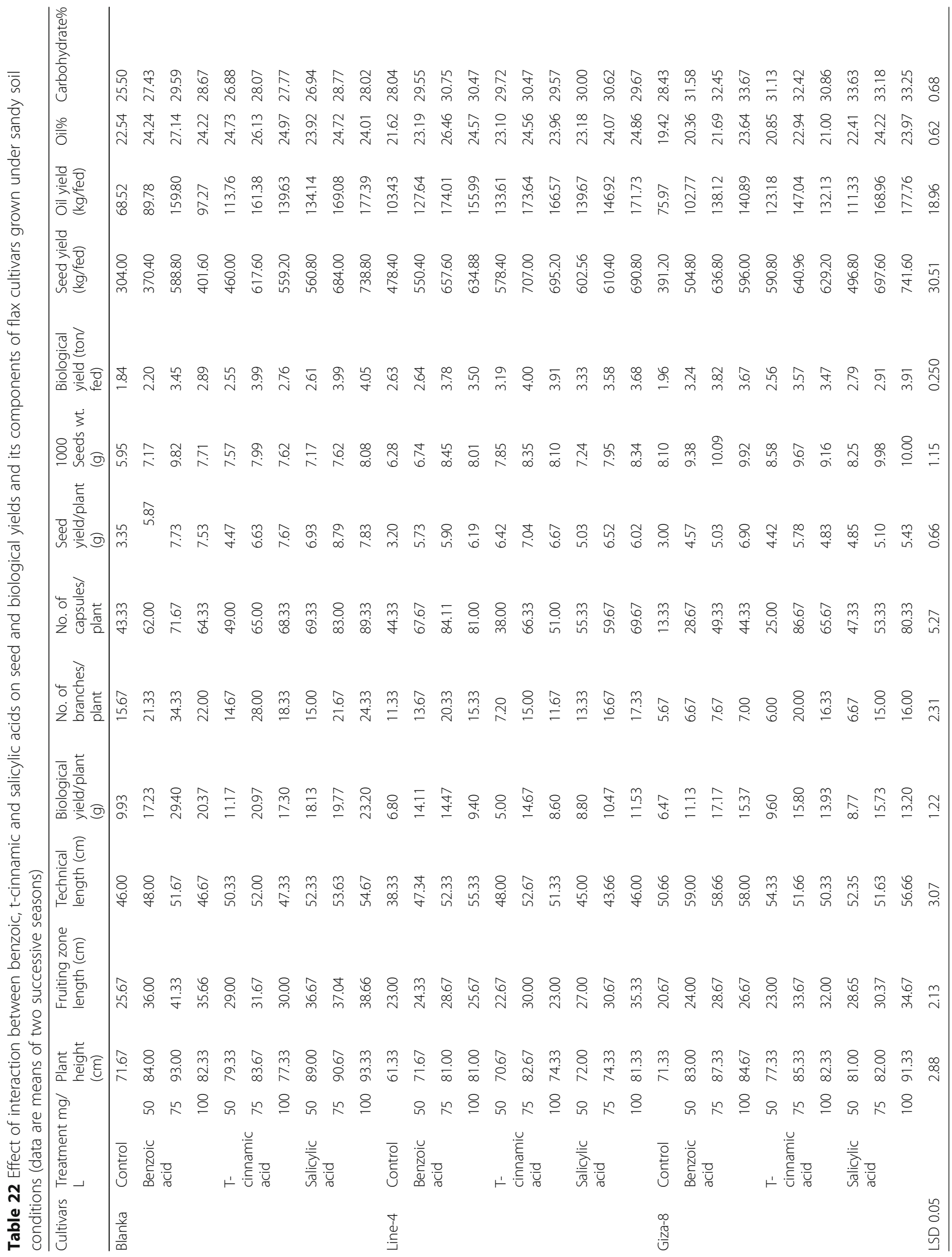


increases in their weights. Moreover, the results show that the different treatment increased oil\% and carbohydrate\% of the yielded seeds. The enhancing effects of different treatments might be due to their effect on activity of different enzymes and translocation of the metabolites to the yielded seeds. In addition, the increases in oil\% may be due to the increase in vegetative growth and nutrient uptake (Bukhsh et al. 2009 and Anjum et al. 2013) . Moreover, the promotive effect of benzoic acid and $t-$ cinnamic acid which are precursors of salicylic acid might be attributed to their bioregulator effects on physiological and biochemical processes in plants. Sadak et al. (2013) stated that benzoic acid treatment increased growth parameters and photosynthetic pigments of soybean plant. El-Awadi et al. (2016) reported that foliar treatment of $\mathrm{t}$-cinnamic acid and benzoic acid enhanced the vegetative growth termis plants, especially at $100 \mu \mathrm{M}$. The enhancing effect of different treatments on yield quantity and quality might be due to their effect on activity of different enzymes and translocation of the metabolites to the yielded seeds.

\section{Conclusion}

It could be concluded that different concentrations of benzoic acid, t-cinnamic acid, and salicylic acid caused significant increases in different growth parameters, seed yield quality, and quantity via improving some biochemical aspects.

\section{Abbreviation \\ IAA: Indole acetic acid}

\section{Acknowledgements}

Not applicable

\section{Authors' contributions}

MGD and MSS designed and performed the experiment, were responsible for all the physiological and biochemical analysis, and also wrote and reviewed the manuscript. BAB and MFEK designed the experiment, farming plants, and statistical analysis. All authors share in every step of this work, and all of them contribute to writing the manuscript. All authors read and approved the final manuscript.

\section{Funding}

Not applicable

\section{Availability of data and materials}

Not applicable

\section{Ethics approval and consent to participate}

Not applicable

\section{Consent for publication}

Not applicable

\section{Competing interests}

The authors declare that they have no competing interests.

\section{Author details}

'Botany Department, Agricultural and Biological Division, National Research Centre, Giza P.O. 12622, Egypt. ${ }^{2}$ Field Crops Research Department,
Agricultural and Biological Division, National Research Centre, Giza P.O. 12622, Egypt.

Received: 11 April 2019 Accepted: 21 June 2019

Published online: 16 July 2019

\section{References}

Abd El-Hamid EM, Sh SM (2012) Performance of flax cultivars in response to exogenous application of salicylic acid under salinity stress. J Applied Sci Res. 8:5081-5088

Abd Elkader MAl, Fahmy AA, Elakkad HA, Hussein Sh S (2018) Response of Nigella sativa growth, productivity and chemical constituents to foliar application by some antioxidant compounds. Biosci Res. 15:3214-3230

Afifi MH, Khalifa R Kh M, Khattab EA, El-Dewiny CY (2014) Response of two flax cultivars to different sources of organic and bio fertilizers addition under newly reclaimed sandy soil conditions. Middle East J of Agric Res. 3:311-317

Anjum Sh A, Ehsanullah L, Xue L, Wang MF, Saleem F, Ch H (2013) Exogenous benzoic acid (BZA) treatment can induce drought tolerance in soybean plants by improving gas-exchange and chlorophyll contents. Australian J Crop Sci. 75:555-560

Bakhoum GS, Abd ELMoneem EB, Sadak MS (2019) Kabesh, Amin G A. Improving growth, some biochemical aspects and yield of three cultivars of soybean plant by methionine treatment under sandy soil condition. Inter J Environ Res. 13:14-22

Bakry AB, El-Hariri DM, Sadak MS, El-Bassiouny HMS (2012) Drought stress mitigation by foliar application of salicylic acid in two linseed varieties grown under newly reclaimed sandy soils. J Applied Sci Res. 8:3503-3514

Blokhina O, Virolainen E, Fagerstedt KV (2003) Antioxidants, oxidative damage and oxygen deprivations stress. (A review). Ann Bot. 91:179-194

Bukhsh M, Malik AU, Ishaque M, Sadiq SH (2009) Performance of sunflower in response to exogenously applied salicylic acid under varying irrigation regimes. The J Animal and Plant Sci. 19:130-134

Chapman HD, Pratt PF (1978) Methods of analysis for soils, plant and water. Univ California Div Agric Sci. Priced Publication

Danil AD, George CM (1972) Peach seed dormancy in relation to endogenous inhibitors and applied growth substances. J American Society for Hortic Sci. 17:621-624

Dawood MG, Sadak MS, Hozayen M (2012) Physiological role of salicylic acid in improving performance, yield and some biochemical aspects of sunflower plant grown under newly reclaimed sandy soil. Australian J Basic Applied Sci. 6:82-89

Dixon RA (2001) Natural products and plant disease resistance. Nature. 411:843-847

Dubey MP (2001) Response of late- planted linseed (Linum usitatissmum L.) varieties to nitrogen levels under rain fed conditions. Indian J Agro. 46:547-551

El Hariri DM, Sadak MS, El-Bassiouny HMS (2010) Response of flax cultivars to ascorbic acid and a-tocopherol under salinity stress conditions. Inter J Academic Res. 2:263-270

El-Awadi ME, Abdel-Baky YR, Sadak M, Sh ABAA, Dawood MG (2016) Physiological response of Lupinus termis to trans-cinammic acid and benzoic acid treatments under sandy soil conditions. Res J Pharm Biol Chem Sci. 7:120-129

Epifano F, Curini M, Genovese S, Blaskovich MA, Hamilton SM (2007) Prenyloxyphenyl propanoids as novel lead compounds for the selective inhibition of geranylgeranyl transferase I. Bioorg Med Chem Lett 17:2639-2642

Herbert D, Phipps PJ, Strange RE (1971) Chemical analysis of microbial cells. Methods Microbio. 5:209-344

Hoskins JA (1984) The occurrence, metabolism and toxicity of cinnamic acid and related compounds. J Applied Toxicol. 14:283-292

Johnson M, Ostlund S, Fransson G, Kadesjö B, Gillberg C (2008) Omega-3/omega6 fatty acids for attention deficit hyperactivity disorder: a randomized placebo-controlled trial in children and adolescents. J Atten Disord PMID.: 1844-8859

Kates M, Eberhardt FM (1957) Isolation and fractionation of leaf phospholipids. Can J Bot. 35:895-905

Khalifa R Kh M, Manal FM, Bakry AB, Zeidan MS (2011) Response of some flax varieties to micronutrients foliar application under newly reclaimed sandy soil. Australian J Basic Applied Sci. 5:1328-1334

Kineber MEA, El-Emary FA, El-Nady MF (2006) Botanical studies on some fibrous flax (Linum usitatissmum L.) genotypes grown under Delta conditions. J Agric Sci. Mansoura Univ. 31:2881-2890

Kineber MEA, El-Sayed SA (2004) Studies on some economic characteristics in flax (Linum usitatissmum L.) in North Delta region of Egypt. Annals Agric Sci Ain Shams Univ Cairo. 49:71-81 
Larsen P, Harbo A, Klungron S, Ashein TA (1962) On the biosynthesis of some indole compounds in Acetobacter Xylinum. Physiologia Plantarum. 15:552-565

Lichtenthaler HK, Buschmann C (2001) Chlorophylls and carotenoids: measurement and characterization by UV-VIS spectroscopy. In: Wrolstad RE, Acree TE, An H, Decker EA, Penner MH, Reid DS, Schwartz SJ, Shoemaker CF, Sporns P (eds) Current protocols in food analytical chemistry (CPFA). John Wiley and Sons, New York, pp F4.3.1-F4.3.8

Makoi JHJR, Ndakidemi PA (2007) Biological, ecological and agronomic significance of plant phenolic compounds in rhizosphere of the symbiotic legumes. Afr J Biotechnol. 6:1358-1368

Morris DH. Flax-a smart choice. New flax facts. Flax Council of Canada, 2005;465167 Lombard Ave., Winnipeg, MB, Canada R3B 0 T6, Website: www. flaxcouncil.ca

Ne'meth M, Janda T, Horva'th E, Pa'ldi E, Szalai G (2008) Environmental and experimental botany. Plant Sci. 64:105-112

Raskin I (1992) Role of salicylic acid in plants. Annual Rev Plant Physiol Mole Biol. 43:439-463

Sadak MS, El-Lethy SR, Dawood MG (2013) Physiological role of benzoic acid and salicylic acid on growth, yield, some biochemical and antioxidant aspects of soybean plant. World J Agric Sci. 9:435-442

Sadak MS, Orabi SA, Bakry BA (2015) Antioxidant properties, secondary metabolites and yield as affected by application of antioxidants and banana peel extract on Roselle plants. American-Eurasian J sustainable agric. 9:93-104

Sadak MS (2016) Physiological role of signal molecules in improving plant tolerance under abiotic stress. Review article. Inter J Chem Tech. 9:46-60

Saruhan NS, Kadioglu A (2012) Salicylic acid pretreatment induces drought tolerance and delays leaf rolling by inducing antioxidant systems in maize genotypes. Acta Physiol Plant. 34:97-106

Senaratna TD, Merritt K, Dixon E, Bunn D, Touchell S, Sivasithamparam K (2003) Benzoic acid may act as the functional group in salicylic acid and derivatives in the induction of multiple stress tolerance in plants. Plant Growth Regul. 39:77-81

Shi GR, Cai QS, Liu QQ, Wu L (2009) Salicylic acid-mediated alleviation of cadmium toxicity in hemp plants in relation to cadmium uptake, photosynthesis, and antioxidant enzymes. Acta Physiol Plant. 31:969-977

Simaei M, Khavarinejad RA, Saadatmand S, Bernard FH (2011) Interactive effects of salicylic acid and nitric oxide on soybean plants under $\mathrm{NaCl}$ salinity. Russ $J$ Plant Physiol. 58:783-790

Snedecor GW, Cochran WG (1980) Statistical methods 7th ed. The lowa State Univ., Press, Ames, IA

Szepesi A, Cciszar J, Bajkan S, Gemes K, Horvath F, Erdei L, Deer AK, Simon ML, Tari I (2005) Role of salicylic acid pretreatment on the acclimation of tomato plants to salt and osmotic stress. Acta Biol Szeged. 49:123-125

Talaat I, Khattab HI, Ahmed AM (2014) Changes in growth, hormones levels and essential oil content of Ammi visnaga L. plants treated with some bioregulators. Saudi J Biol Sci. 21:355-365

Thimann KV. The Auxins. In: Physiology of plant growth and development, M.B. Wilkinson (ed.), 1969; pp:2-45, Accession Number 1970:51751 CAN: 72:51751 CAPLUS McGraw-Hill, London.

Wang LJ, Fan L, Loescher W, Duan W, Liu GJ, Cheng JS, Luo HB, Li SH (2010) Salicylic acid alleviates decreases in photosynthesis under heat stress and accelerates recovery in grapevine leaves. BMC Plant Biol. 10:34. https://doi. org/10.1186/1471-2229-10-34

\section{Publisher's Note}

Springer Nature remains neutral with regard to jurisdictional claims in published maps and institutional affiliations.

\section{Submit your manuscript to a SpringerOpen ${ }^{\circ}$ journal and benefit from:}

- Convenient online submission

- Rigorous peer review

- Open access: articles freely available online

- High visibility within the field

- Retaining the copyright to your article

Submit your next manuscript at $\boldsymbol{\nabla}$ springeropen.com 